ISSN: 2302-8556

E-Jurnal Akuntansi

Vol.28.2.Agustus (2019): 1012-1035

DOI: https://doi.org/10.24843/EJA.2019.v28.i02.p09

\title{
Pengaruh Pemahaman Kode Etik Akuntan, Kecerdasan Emosional, dan Religiusitas terhadap Perilaku Etis Mahasiswa Akuntansi
}

\author{
I Komang Raditya Wiguna ${ }^{1}$ \\ I Ketut Suryanawa ${ }^{2}$ \\ 1,2 Fakultas Ekonomi dan Bisnis Universitas Udayana (Unud), Bali, Indonesia \\ e-mail : raditwiguna@gmail.com
}

\begin{abstract}
ABSTRAK
Tujuan dari penelitian ini adalah untuk mengetahui pengaruh Pemahaman Kode Etik Akuntan, Kecerdasan Emosional, dan Religiusitas Terhadap Perilaku Etis Mahasiswa Akuntansi. Penelitian ini menggunakan teknik analisis regresi linear berganda. Dalam penentuan sampel penelitian ini menggunakan rumus Slovin. Dari hasil perhitungan didapatkan bahwa sampel berjumlah minimal 75 orang responden yang merupakan mahasiswa aktif angkatan 2015 dan telah menempuh mata kuliah pengauditan 1. Jenis data yang digunakan dalam penelitian ini adalah data kuantitatif, yang berupa hasil jawaban oleh responden yang dinyatakan dalam bentuk angka-angka dari kuesioner yang diukur menggunakan skala Likert. Hasil analisis menunjukkan bahwa, pemahaman kode etik akuntan, kecerdasan emosional, dan religiusitas berpengaruh positif terhadap perilaku etis mahasiswa akuntansi.
\end{abstract}

Kata kunci: Pemahaman kode etik akuntan, kecerdasan emosional, religiusitas, perilaku etis.

\begin{abstract}
The purpose of this study was to determine the effect of Understanding the Code of Ethics of Accountants, Emotional Intelligence, and Religiosity on Ethical Behavior of Accounting Students. This study uses multiple linear regression analysis techniques. In determining the sample of this study using Slovin formula. From the calculation results, it was found that the sample amounted to at least 75 respondents who were active students of the class of 2015 and had taken auditing courses 1. The type of data used in this study is quantitative data, in the form of answers from respondents stated in the form of numbers from the questionnaire was measured using a Likert scale. The results of the analysis show that the understanding of the accountant's code of ethics, emotional intelligence, and religiosity positively influences the ethical behavior of accounting students.

Keywords: Understanding of the accountant's code of ethics, emotional intelligence, religiosity, ethical behavior.
\end{abstract}

\section{PENDAHULUAN}

Skandal Enron merupakan skandal yang berdampak sangat besar pada profesi akuntan publik. Rekayasa akuntansi yang sengaja dilakukan membuat masyarakat semakin mempertanyakan etika akuntan. di Indonesia juga terjadi skandal mengenai etika akuntan. Akuntan Publik (AP) Justinus Aditya Sidharta gagal 
menemukan indikasi penggelembungan akun penjualan, piutang dan aset yang menjadikan AP Justinus Aditya Sidartha tersangka. Karena kegagalan tersebut, PT Great River Internatinal Tbk menyajikan laporan keuangan yang tidak sebenarnya dan dianggap melakukan kebohongan publik. Dengan terlibatnya AP Justinus Aditya, Menteri Keuangan Indonesia membekukan izin akuntan publik milik AP Justinus Aditya. Pelanggaran integritas berarti seseorang telah melanggar aturanaturan yang telah disepakati secara umum. Sedangkan objektivitas merupakan pernyataan jujur dan apa adanya terhadap suatu hal. Kemudian sikap skeptisisme profesional auditor yang harus dimiliki seharusnya dapat mengungkapkan adanya indikasi kecurangan atau kesalahan-kesalahan yang ada dalam laporan keuangan yang telah disajikan oleh perusahaan.

Individu yang memiliki pemahaman mengenai sesuatu yang diizinkan serta tidak diizinkan yang sesuai norma di masyarakat, berarti individu tersebut memiliki etika. Menurut Chan 2006) ilmu yang mempelajari mengenai apa yang baik dan tidak juga dapat disebut etika. Ketika individu melakukan pekerjaan terdapat etika-etika dalam pekerjaan yang harus diikuti oleh individu tersebut. Aturan tersebut merupakan aturan tertulis. Professionalisme individu tersebut dapat dilihat dari seberapa baik individu tersebut dalam melakukan pekerjaan sesuai dengan aturan tertulis mengenai etika yang telah ditetapkan. Aturan tertulis tersebut disebut dengan kode etik (Mulyadi, 2002). Perilaku yang beretika dalam organisasi adalah melaksanakan tindakan secara fair sesuai hukum konstitusional dan peraturan pemerintah yang dapat diaplikasikan (Reiss \& Mitra, 1998). Pemimpin dalam organisasi merupakan role model bagi anggotanya. Ketika 
pemimpin dapat memberikan contoh perilaku yang baik maka anggota tim cenderung akan memiliki perilaku yang baik juga. Begitu juga dengan kepatuhan pemimpin terhadap kode etik dari profesi yang dijalaninya. Dengan memiliki pemimpin atau individu yang patuh terhadap kode etik profesi yang berlaku maka individu tersebut dapat dikatakan sukses karena berperilaku etis dalam pekerjaan merupakan faktor penting dalam mencapai kesuksesan dalam karir seseoraang (Morgan, 1993). Menurut Larkin (2000) memiliki pengetahuan untuk dapat melihat perilaku yang dikategorikan etis dan yang tidak dikategorikan etis sangat berguna baagi semua profesi begitu juga profesi akuntan. Keahlian yang diperoleh dari lembaga pendidikan khusus diperuntukkan untuk itu dengan kurikulum yang dapat dipertanggungjawabkan (Revita Mardawati, 2016).

Akuntan memiliki tugas yang berhubungan dengan laporan keuangan. Setiap perusahaan memiliki laporan keuangan terutama perusahaan yang telah go public perlu menerbitkan laporan keuangan yang telah diaudit yang kemudian digunakan oleh orang-orang yang memerlukan laporan keuangan tersebut dalam menentukan suatu keputusan. Pengauditan tersebut merupakan salah satu dari beberapa tugas akuntan. Akuntan perlu memberikan pendapat mengenai kewajaran dari penyajian laporan keuangan. Untuk mendapatkan pendapat bahwa laporan keuangan telah disajikan secara wajar, laporan keuangan tersebut harus disajikan sesuai dengan standar akuntansi keuangan yang berlaku. Profesi akuntan di Indonesia memiliki "Kode Etik Akuntan Indonesia" yang telah mengalami revisi terakhir pada tahun 1998 dan disahkan oleh IAI atau Ikatan Akuntansi Indonesia. 
Wibowo (1986) dalam penelitiannya mengenai kode etik akuntan menemukan hasil yaitu pengaruh positif dari kode etik akuntan terhadap perilaku etis dan pertimbangan etis auditor. Ernawati \& Susanti (2016) juga menemukan hal yang serupa dalam penelitian yang dilakukannya. Ernawati \& Susanti (2016) selanjutnya memaparkan pentingnya profesionalisme bagi profesi. Akuntan memiliki tugas yang berhubungan dengan laporan keuangan. Setiap perusahaan memiliki laporan keuangan terutama perusahaan yang telah go public perlu menerbitkan laporan keuangan yang telah diaudit yang kemudian digunakan oleh orang-orang yang memerlukan laporan keuangan tersebut dalam menentukan suatu keputusan. Akuntan memiliki tanggung jawab terhadap masyarakat untuk memastikan bahwa laporan yang disajikan telah sesuai dengan SAK sehingga tidak terjadi kesalahan dalam pengambilan keputusan oleh pengguna laporan keuangan. Pengetahuan mengenai kode etik akuntan harus sudah ditanamkan sejak seseorang tersebut menempuh pendidikan untuk menjadi seorang akuntan. Oleh karena itu kode etik merupakan faktor penting untuk diketahui dan dimengerti oleh mahasiswa akuntansi. Davis \& Welton (1991) dengan judu penelitian "Profesional Ethics: Business Student's Perceptions" tidak menemukan adanya pengaruh dari kode etik terhadap professional ethics.

Menurut Melandy \& Nurma (2006) yang dimaksud dengan kecerdasan emosional adalah bagaimana individu dapat mengendalikan emosi yang dimilikinya menjadi sesuatu yang memiliki dampak positif. Svyantek (2003) berpendapat bahwa seseorang yang memiliki kecerdasan emosional maka orang 
tersebut dapat mengetahui bagaimana perasaan dirinya sendiri serta perasaan orang lain disekitarnya. Keterampilan sosial atau kemampuan dalam membina hubungan dengan orang lain adalah kemampuan individu untuk berkomunikasi efektif dengan orang lain baik secara verbal maupun nonverbal sesuai dengan situasi dan kondisi yang ada pada saat itu, di mana keterampilan ini merupakan perilaku yang dipelajari (Wiyono, 2012). Individu yang memiliki kecerdasan emosional akan memanfaatkan kemampuannya dalam memahami perasaan tersebut untuk mengendalikan pikirannya dalam bertindak agar tidak mengecewakan ataupun merugikan orang lain. Catarina $(2010 ; 24)$ berpendapat dengan kemampuan seseorang dalam mengatur emosinya dengan baik, individu tersebut akan memiliki motivasi untuk melakukan pengembangan terhadap potensi yang dimilikinya. Peningkatan potensi tersebut kemudian akan berdampak pada peningkatan kualitas dari sumber daya manusia.

Kecerdasan sprititual yaitu individu tersebut memiliki kejujuran, terbuka, memiliki pengetahuan terhadap dirinya, dan memiliki pikiran yang terpusat pada kontribusi untuk dirinya (Setyawan, 2004). Menurut Zohar \& Marshall (2007) individu dalam melakukan tindakan tertentu, mempertimbangkan mengenai agama atau kepercayaan yang dipegang oleh individu tersebut. Tindakan tertentu tersebut dapat terkait dari bagaimana individu tersebut menyelesaikan masalah yang memerlukan kecerdasan spiritual dalam mengambil keputusannya. Individu yang dengan kecerdasan spiritual yang baik cenderung menggunakan pengalamannya sebagai penerapan bentuk dan nilai (Yanti, 2012).

Simanjorang \& Sipayung (2012) dalam penelitiannya menemukan 
kecerdasan intelektual,emosional, dan spiritual memiliki pengaruh yang positif pada perilaku etis mahasiswa. Lucyanda (2013) juga menemukan hasil yang sama dalam penelitiannya. Lucyanda (2013) selanjutnya mengemukakan bahwa kecerdasan emosional memiliki pengaruh yang cenderung dominan jika dibandingkan dengan kecerdasan lain yang menjadi variabel dalam penelitiannya. Alasan dari temuan tersebut adalah dengan berkembangnya kecerdasan emosional seseorang akan diikuti dengan perkembangan kecerdasan lainnya. dan Said \& Rahmawati (2019) dalam penelitiannya menemukan bahwa kecerdasan intelektual, kecerdasan emosional dan kecerdasan spiritual berpengaruh terhadap sikap etis dari mahasiswa akuntansi.

Teori etika merupakan suatu kerangka pemikiran sistematis mengenai prinsip-prinsip etika yang umum pada perilaku manusia. Teori etika menyediakan kerangka yang memungkinkan kita memastikan benar tidaknya keputusan moral yang kita ambil (Bertens, 2000). Pertimbangan di dalam mengambil tindakan yang dapat dibenarkan secara etika.

Menurut Green \& Kreuter (2000), perilaku ialah hasil proses interaksi manusia dengan lingkungannya dan juga pengalamannya dimana terwujud dalam bentuk sikap, pengetahuan, serta tindakan. Sikap menyangkut komponen kognitif terkait keyakinan, komponen sikap afektif berkonotasi suka atau tidak suka, sedangkan tingkah laku merupakan perwujudan dalam bentuk tindakan suatu objek (Ramly,2008).

Pemimpin dalam organisasi merupakan role model bagi anggotanya. Ketika pemimpin dapat memberikan contoh perilaku yang baik maka anggota tim 
cenderung akan memiliki perilaku yang baik juga. Begitu juga dengan kepatuhan pemimpin terhadap kode etik dari profesi yang dijalaninya. Dengan memiliki pemimpin atau individu yang patuh terhadap kode etik profesi yang berlaku maka individu tersebut dapat dikatakan sukses karena berperilaku etis dalam pekerjaan merupakan faktor penting dalam mencapai kesuksesan dalam karir seseorang (Morgan, 1993).

Individu yang memiliki pemahaman mengenai sesuatu yang diizinkan serta tidak diizinkan yang sesuai norma di masyarakat, berarti individu tersebut memiliki etika. Menurut Chan (2006) ilmu yang mempelajari mengenai apa yang baik dan tidak juga dapat disebut etika. Professionalisme individu tersebut dapat dilihat dari seberapa baik individu tersebut dalam melakukan pekerjaan sesuai dengan aturan tertulis mengenai etika yang telah ditetapkan. Aturan tertulis tersebut disebut dengan kode etik (Mulyadi, 2002)

Menurut Goleman (2002) kecerdasan emosional adalah bagaimana individu memahami keadaan emosional pada dirinya sendiri dan memanfaatkannya kearah yang lebih positif. Individu dengan kecerdasann emosional cenderung akan lebih bijak. Tikollah, Triyuwono, \& Ludigdo (2006) memaparkan bahwa yang dimaksud dengan kecerdasaan emosional adalah bagaimana seseorang dapat memahami dan mengatur emosi yang dimiliki. Sejalan dengan hal tersebut Svyantek (2003) memberikan penjelasan bahwa seseorang yang mengetahui bagaimana perasaannya dan bagaimana perasaan orang-orang di sekitarnya merupakan orang yang memiliki kecerdasaan emosional.

Yakin dan percaya terhadap nilai-nilai yang menyangkut keagamaan dan 
suatu tujuan tertentu dapat disebut dengan religiusitas. Memiliki ketetapan atau berkomitmen terhadap Tuhan dengan mematuhi segala perintah dan laranganNya juga disebut dengan religiusitas (McDaniel, S.W . \& Burnett, J.J., 1990)

Enofe, Nakpodia, \& Moruku (2014) dalam penelitiannya menemukan bahwa terdapat pengaruh dari kode etik terhadap parktik kerja akuntan. dengan hasil yang didaapatkan tersebut, maka penting adanya pemberian pengetahuan mengenai kode etik akuntan kepada mahasiswaa akuntansi karena mahasiswa akuntansi adalah calon-calon akuntan di masa yang akan datang. Dengan memberikan pengetahuan mengenai kode etik sejak masa perkuliahan, diharapkan akan meningkatkan kebiasaan mahasiswa dalam berperilaku etis dan kemudian akan terbawa ke dunia kerjanya nanti. Wibowo (1986) dan Gberegbe \& Gabriel (2016) dalam penelitiannya mengenai kode etik akuntan menemukan hasil yaitu pengaruh positif dari kode etik akuntan terhadap perilaku etis dan pertimbangan etis auditor. Ernawati \& Susanti (2016) juga menemukan hal yang serupa dalam penelitian yang dilakukannya. Ernawati \& Susanti (2016) selanjutnya memaparkan pentingnya profesionalisme bagi profesi. Akuntan memiliki tugas yang berhubungan dengan laporan keuangan. Setiap perusahaan memiliki laporan keuangan terutama perusahaan yang telah go public perlu menerbitkan laporan keuangan yang telah diaudit yang kemudian digunakan oleh orang-orang yang memerlukan laporan keuangan tersebut dalam menentukan suatu keputusan. Akuntan memiliki tanggung jawab terhadap masyarakat untuk memastikan bahwa laporan yang disajikan telah sesuai dengan SAK sehingga tidak terjadi kesalahan dalam pengambilan keputusan oleh pengguna laporan keuangan. 
$\mathrm{H}_{1}$ : Pemahaman Kode Etik Akuntan berpengaruh positif terhadap Perilaku Etis Mahasiswa Akuntansi.

Dalam penelitian Simanjorang \& Sipayung (2012) mahasiswa dengan kecerdasan Emosional yang baik akan memiliki Perilaku Etis yang baik juga. Seseorang dengan kecerdasan emosional yang baik lebih mampu beradaptasi dengan keadaan. Penelitian ini sejalan juga dengan hasil penelitian Said \& Rahmawati (2019) dan Higgs (2014), penelitian mereka mendukung hipotesis penelitian ini terutama variabel kecerdasan emosional yang memiliki pengaruh positif terhadap perilaku etis mahasiswa. Berdasarkan uraian diatas, maka diajukan hipotesis penelitian sebagai berikut ini:

$\mathrm{H}_{2}$ : Kecerdasan Emosional berpengaruh positif terhadap Perilaku Etis Pada Mahasiswa Akuntansi.

Handayani (2010) dengan judul penelitian "Faktor-Faktor yang Mempengaruhi Perilaku Etis Mahasiswa Akuntansi Universitas Islam Lamongan” mendapatkan hasil semakin baiknya tingkat kecerdasan spiritual mahasiswa akan berdampak terdahap baiknya perilaaku etis mahasiswa tersebut. Riasning, Datrini, \& Putra (2017) memberikan penjelasan mengenai bagaimana seseorang dengan tingkat kecerdasan spiritual tinggi cenderung memilih untuk mengembangkan dirinya pada aktivitas yang positif. Lucyanda (2013) mengungkapkan mahasiswa dengan kecerdasan spiritual yang tinggi cenderung mempertimbangkan perilakunya dan selalu berpikir untuk berperilaku yang tidak menyimpang.

$\mathrm{H}_{3}$ : Religiusitas berpengaruh positif terhadap Perilaku Etis Pada Mahasiswa Akuntansi.

\section{METODE PENELITIAN}

Fakultas Ekonomi dan Bisnis Universitas Udayana merupakan lokasi dari 
penelitian ini. Objek penelitian dalam penelitian ini adalah Pengaruh Pemahaman Kode Etik Akuntan, Kecerdasan Emosional, dan Religiusitas Terhadap Perilaku Etis Mahasiswa S1 Akuntansi Universitas Udayana Bali Angkatan 2015. Angkatan 2015 digunakan karena merupakan angkatan tertua dan akan memasuki dunia kerja.

Perilaku Etis Mahasiswa Akuntansi merupakan dependent variable yang digunakan. Variabel independen merupakan variabel yang dapat mengakibatkan perubahan pada varibel dependen. Variabel Independen yang digunakan dalam penelitian ini yaitu Pemahamam Kode Etik Akuntan, Kecerdasan Emosional, dan Religiusitas.

Individu yang memiliki pemahaman mengenai sesuatu yang diizinkan serta tidak diizinkan yang sesuai norma di masyarakat, berarti individu tersebut memiliki etika. Menurut Chan (2006) ilmu yang mempelajari mengenai apa yang baik dan tidak juga dapat disebut etika. Individu yang memahami konsep etika dan melakukan hal-hal yang dianggap sesuai dengan konsep tersebut maka dapat disebut individu tersebut berperilaku etis.

Ketika individu melakukan pekerjaan terdapat etika-etika dalam pekerjaan yang harus diikuti oleh individu tersebut. Aturan tersebut merupakan aturan tertulis. Professionalisme individu tersebut dapat dilihat dari seberapa baik individu tersebut dalam melakukan pekerjaan sesuai dengan aturan tertulis mengenai etika yang telah ditetapkan. Aturan tertulis tersebut disebut dengan kode etik (Mulyadi, 2002). 
Menurut Goleman (2002) kecerdasan emosional adalah bagaimana individu memahami keadaan emosional pada dirinya sendiri dan memanfaatkannya kearah yang lebih positif. Individu dengan kecerdasann emosional cenderung akan lebih bijak. (Tikollah et al., 2006) memaparkan bahwa yang dimaksud dengan kecerdasaan emosional adalah bagaimana seseorang dapat memahami dan mengatur emosi yang dimiliki. Sejalan dengan hal tersebut Svyantek (2003) memberikan penjelasan bahwa seseorang yang mengetahui bagaimana perasaannya dan bagaimana perasaan orang-orang di sekitarnya merupakan orang yang memiliki kecerdasaan emosional.

Yakin dan percaya terhadap nilai-nilai yang menyangkut keagamaan dan suatu tujuan tertentu dapat disebut dengan religiusitas. Memiliki ketetapan atau berkomitmen terhadap Tuhan dengan mematuhi segala perintah dan laranganNya juga disebut dengan religiusitas (McDaniel, S.W . \& Burnett, J.J., 1990)

Teknik pengumpulan data yang digunakan dalam penelitian ini adalah kuesioner. Jenis data dalam penelitian ini menggunakan data kuantitatif. Data kuantitatif dalam penelitian ini diperoleh melalui hasil scoring dari jawaban para responden terhadap kuesioner yang telah dibagikan.

Populasi dalam penelitian ini adalah seluruh mahasiswa S1 akuntansi UNUD angkatan 2015 Berjumlah 349 orang, alasan peneliti menggunakan angkatan 2015 dikarenakan angkatan 2015 merupakan angkatan tertua dan akan menempuh dunia kerja.

Teknik pengambilan sampel menggunakan teknik accidental sampling dan purposive sampling dengan kriteria mahasiswa telah menempuh mata kuliah 
Pengauditan I, karena Pemahaman Kode Etik Akuntan diajarkan pada matakuliah Pengauditan I, merupakan mahasiswa berstatus aktif.

Metode pengumpulan sampel yang digunakan adalah non probability sampling dengan menggunakan teknik purposive sampling dan accidental sampling. Penentuan sampel menggunakan rumus Slovin. Karena jumlah mahasiswa yang memenuhi syarat sangat besar, maka digunakan rumus Slovin dalam menentukan sampelnya (Husein, 2008). Jenis data berdasarkan sumber data primer. Data primer diperoleh dengan menggunakan kuesioner.

\section{HASIL DAN PEMBAHASAN}

Data penelitian dikumpulkan dengan menyebarkan kuesioner dengan cara memberikan pertanyaan kuesioner secara online dengan menggunakan google formulir kepada mahasiswa S1 akuntansi Fakultas Ekonomi dan Bisnis Universitas Udayana di Bali. Penyebaran kuesioner dimulai dari 24 Januari sampai dengan 27 Januari 2019. Kuesioner yang disebar oleh peneliti sebanyak 75 kuesioner dan disebar menggunakan sarana sosial media. Dari keseluruhan kuesioner yang disebar melalui google formulir, kuesioner sebanyak 75 secara keseluruhan dijawab oleh responden.

Tabel 1.

Karakteristik Responden

\begin{tabular}{llll}
\hline No & Karakteristik Responden & $\begin{array}{l}\text { Jumlah } \\
\text { Orang }\end{array}$ & Persentase (\%) \\
\hline 1. & Jenis Kelamin & 41 & 54,7 \\
& Laki-laki & 34 & 45,3 \\
& Perempuan & 75 & 100 \\
& Total & & \\
& & & \\
& & & \\
& & & \\
\hline
\end{tabular}


ISSN: 2302-8556

E-Jurnal Akuntansi

Vol.28.2.Agustus (2019): 1012-1035

\begin{tabular}{ccc}
\hline 2015 & 75 & 100 \\
Total & 75 & 100 \\
\hline
\end{tabular}

Sumber: Data diolah, 2019

Hasil uji validitas menunjukkan bahwa semua instrument penelitian yang digunakan untuk mengukur variabel penelitian memiliki Pearson Correlation diatas 0,3 sehingga dinyatakan valid.

Tabel 2.

Hasil Uji Reliabilitas

\begin{tabular}{|c|c|c|c|}
\hline No & Variabel & Cronbach's Alpha & Keterangan \\
\hline 1 & $\begin{array}{l}\text { Perilaku Etis } \\
\text { Mahasiswa Akuntansi } \\
\text { (Y1) }\end{array}$ & 0,940 & Reliabel \\
\hline 2 & $\begin{array}{l}\text { Pemahaman Kode } \\
\text { Etik Akuntan (X1) }\end{array}$ & 0,974 & Reliabel \\
\hline 3 & $\begin{array}{l}\text { Kecerdasan } \\
\text { Emosional (X2) }\end{array}$ & 0,910 & Reliabel \\
\hline 4 & Religiusitas (X3) & 0,920 & Reliabel \\
\hline
\end{tabular}

Sumber: Data diolah, 2019

Suatu instrumen dikatakan reliabel apabila instrumen tersebut mempunyai nilai Cronbach's Alpha lebih besar dari 0,6. Hasil uji reliabilitas yang menunjukkan bahwa semua variabel yang digunakan dalam penelitian ini memiliki nilai koefisien yang melebihi 0,6 yang berarti semua variabel yang digunkan dalam penelitian ini reliable dan layak digunakan.

Tabel 3.

Hasil Statistik Deskriptif

\begin{tabular}{|c|c|c|c|c|c|}
\hline Variabel & $\mathrm{N}$ & Min. & Max. & Mean & Std. Deviasi \\
\hline $\begin{array}{l}\text { Perilaku } \\
\text { Etis } \\
\text { Mahasiswa } \\
\text { Akuntansi } \\
\text { (Y) }\end{array}$ & 75 & 20 & 32 & 27,49 & 3,219 \\
\hline $\begin{array}{l}\text { Pemahaman } \\
\text { Kode Etik } \\
\text { Akuntan } \\
\text { (X1) }\end{array}$ & 75 & 44 & 64 & 55,71 & 5,925 \\
\hline $\begin{array}{l}\text { Kecerdasan } \\
\text { Emosional } \\
(\mathrm{X} 2)\end{array}$ & 75 & 23 & 36 & 30,65 & 3,674 \\
\hline $\begin{array}{l}\text { Religiusitas } \\
\text { (X3) }\end{array}$ & 75 & 19 & 32 & 26,99 & 3,359 \\
\hline
\end{tabular}


Sumber: Data diolah,2019

Setelah dilakukan uji statistic deskriptif, didapatkan hasil dari 75 jumlah sampel, variabel Y memiliki nilai min. yaitu 20. Dari 75 jumlah sampel, variabel Y memiliki nilai max. yaitu 32. Mean dari variabel $\mathrm{Y}$ adalah 27,49 dan deviation std. yang didapatkan adalah sebesar 3,219. Menurut penjabaran dari hasil uji statistik deskriptif untuk variabel Y disimpulkan dari 75 responden sebagian besar menyetujui pertanyaan-pertanyaan yang diajukan dalam kuisioner yang berarti perilaku etis mahasiswa akuntansi Universitas Udayana sangat baik.

Setelah dilakukan uji statistic deskriptif, didapatkan hasil dari 75 jumlah sampel, variabel $\mathrm{X}_{1}$ memiliki nilai min. yaitu 44. Dari 75 jumlah sampel, variabel $\mathrm{X}_{1}$ memiliki nilai max. yaitu 64. Mean dari variabel $\mathrm{X}_{1}$ adalah 55,71 dan deviation std. yang didapatkan adalah sebesar 5,925. Menurut penjabaran dari hasil uji statistik deskriptif untuk variabel $X_{1}$ disimpulkan dari 75 responden sebagian besar menyetujui pertanyaan-pertanyaan yang diajukan dalam kuisioner yang berarti pemahaman mahasiswa akuntansi Universitas Udayana terhadap kode etik akuntan yaitu sangat paham.

Setelah dilakukan uji statistic deskriptif, didapatkan hasil dari 75 jumlah sampel, variabel $\mathrm{X}_{2}$ memiliki nilai min. yaitu 23. Dari 75 jumlah sampel, variabel $\mathrm{X}_{2}$ memiliki nilai max. yaitu 36. Mean dari variabel $\mathrm{X}_{2}$ adalah 30,65 dan deviation std. yang didapatkan adalah sebesar 3,674. Menurut penjabaran dari hasil uji statistik deskriptif untuk variabel $\mathrm{X}_{2}$ disimpulkan dari 75 responden sebagian besar cenderung menyetujui pertanyaan-pertanyaan yang diajukan dalam 
kuisioner yang berarti kecerdasan emosional mahasiswa akuntansi Universitas Udayana cenderung tinggi.

Setelah dilakukan uji statistic deskriptif, didapatkan hasil dari 75 jumlah sampel, variabel $\mathrm{X}_{3}$ memiliki nilai min. yaitu 19. Dari 75 jumlah sampel, variabel $\mathrm{X}_{3}$ memiliki nilai max. yaitu 32. Mean dari variabel $\mathrm{X}_{3}$ adalah 26,99 dan deviation std. yang didapatkan adalah sebesar 3,359. Menurut penjabaran dari hasil uji statistik deskriptif untuk variabel $\mathrm{X}_{3}$ disimpulkan dari 75 responden sebagian besar cenderung menyetujui pertanyaan-pertanyaan yang diajukan dalam kuisioner yang berarti artinya tingkat religiusitas mahasiswa akuntansi Universitas Udayana cenderung tinggi.

Tabel 4.

Hasil Uji Normalitas One-Sample Kolmogorov-Smirnov Test

\begin{tabular}{lr}
\hline & Unstandardized Residual \\
\hline N & 75 \\
Kolmogorov-Smirnov Z & 0,954 \\
Asymp. Sig. (2-tailed) & 0,322 \\
\hline
\end{tabular}

Sumber: Data diolah, 2019

Setelah melakukan uji normalitas, didapatkan hasil bahwa model yang digunakan dalam penelitian ini berdistribusi normal. Hal tersebut dapat dilihat dari nilai Sig. yang telah melebihi 0,05 yaitu 0,322 .

Tabel 5.

Hasil Uji Multikolinieritas

\begin{tabular}{llll}
\hline Variabel & Tolerance & VIF & Keterangan \\
\hline $\begin{array}{l}\text { Permahaman Kode } \\
\text { Etik Akuntan }\left(\mathrm{X}_{1}\right)\end{array}$ & 0,342 & 2,924 & Bebas Multikol \\
Kecerdasan & 0,330 & 3,032 & Bebas Multikol \\
Emosional $\left(\mathrm{X}_{2}\right)$ & & & \\
Religiusitas $\left(\mathrm{X}_{3}\right)$ & 0,318 & 3,143 & Bebas Multikol \\
\hline
\end{tabular}

Sumber: Data diolah,2019

Diperlukan nilai tolerance yang melebihi $10 \%$ untuk terbebas dari masalah multikolinearitas dan dalam penelitian ini variabel $\mathrm{X}_{1}$, variabel $\mathrm{X}_{2}$, dan variabel 
$\mathrm{X}_{3}$ berhasil terbebas dari masalah multikolinearitas karena masing-masing variabel memiliki nilai $0,342\left(\mathrm{X}_{1}\right), 0,330\left(\mathrm{X}_{2}\right), 0,318\left(\mathrm{X}_{3}\right)$.

Tabel 6.

Hasil Uji Heteroskedastisitas

\begin{tabular}{|c|c|c|}
\hline Variabel & Signifikansi & Keterangan \\
\hline $\begin{array}{l}\text { Pemahaman Kode Etik } \\
\text { Akuntan }\left(\mathrm{X}_{1}\right)\end{array}$ & 0,394 & Bebas Heteroskedastisitas \\
\hline $\begin{array}{l}\text { Kecerdasan Emosional } \\
\left(\mathrm{X}_{2}\right)\end{array}$ & 0,062 & Bebas Heteroskedastisitas \\
\hline Religiusitas $\left(\mathrm{X}_{3}\right)$ & 0,793 & Bebas Heteroskedastisitas \\
\hline
\end{tabular}

Sumber: Data diolah,2019

Diperlukan signifikansi yang melebihi 0,05 untuk terbebas dari masalah heteroskedastisitas dan dalam penelitian ini variabel $\mathrm{X}_{1}$, variabel $\mathrm{X}_{2}$, dan variabel $\mathrm{X}_{3}$ berhasil terbebas dari masalah heteroskedastisitas karena masing-masing variabel memiliki nilai $0,394\left(X_{1}\right), 0,062\left(X_{2}\right), 0,793\left(X_{3}\right)$.

Tabel 7.

Hasil Analisis Regresi Linier Berganda

\begin{tabular}{lllll}
\hline Model & & Koefisien Regresi & Std. Error & Sig. \\
\hline 1 & (Constant) & 2,914 & 2,109 & \\
& Kode Etik & 0,152 & 0,063 & 0,171 \\
& Kec. Emosional & 0,267 & 0,104 & 0,018 \\
& Religiusitas & 0,293 & 0,115 & 0,013 \\
& $R$ Square & 0,672 & & \\
& Adjusted $R$ Square & 0,658 & & \\
& F hitung & 48,547 & & \\
& Signifikansi F & 0,000 & & \\
\hline
\end{tabular}

Sumber: Data diolah,2019

Berdasarkan hasil analisis regrresi linier berganda seperti yang disajikan pada Tabel 7, maka dapat dibuat persamaan regresi sebagai berikut.

$$
Y=2,914+0,152 X_{1}+0,267 X_{2}+0,293 X_{3}
$$

Nilai konstanta $(\alpha)$ sebesar 2,914 memiliki arti jika variabel pemahaman kode etik akuntan, kecerdasan emosional, dan religiusitas dinyatakan konstan pada angka 0 , maka perilaku etis mahasiswa akuntansi cenderung positif. 
Koefisien regresi $\beta_{1}$ untuk variabel pemahaman kode etik akuntan sebesar 0,152 memiliki arti jika variabel pemahaman kode etik akuntan meningkat maka akan menyebabkan peningkatan pada perilaku etis mahasiswa akuntansi, dengan asumsi variabel bebas lainnya dianggap konstan. Koefisien regresi $\beta_{2}$ untuk variabel kecerdasan emosional sebesar 0,267 memiliki arti jika variabel kecerdasan emosional meningkat maka akan menyebabkan peningkatan pada perilaku etis mahasiswa akuntansi, dengan asumsi variabel bebas lainnya dianggap konstan. Koefisien regresi $\beta_{3}$ untuk variabel religiusitas sebesar 0,293 memiliki arti jika variabel religiusitas meningkat maka akan menyebabkan peningkatan pada perilaku etis mahasiswa akuntansi, dengan asumsi variabel bebas lainnya dianggap

Uji kelayakan model regresi diperoleh nilai $\mathrm{F}$ hitung sebesar 48,547 dengan signifkansi sebesar $0,000<0,05$, maka dapat disimpulkan bahwa pada kelompok yang diuji memiliki perbedaan yang nyata (signifikan). Hasil ini mempunyai arti bahwa ada pengaruh signifikan antara pemahaman kode etik akuntan, kecerdasan emosional, dan religiusitas terhadap perilaku etis mahasiswa akuntansi

Besarnya pengaruh variabel bebas terhadap variabel terikat yang ditunjukkan oleh nilai determinasi total (R Square) sebesar 0,672 mempunyai arti bahwa sebesar $67,2 \%$ variasi perilaku etis mahasiswa akuntansi dipengaruhi oleh variasi pemahaman kode etik akuntan, kecerdasan emosional, dan religiusitas sedangkan sisanya sebesar $32,8 \%$ djelaskan oleh faktor lain yang tidak dimasukkan ke dalam model. 
Pengaruh variabel pemahaman kode etik akuntan, kecerdasan emosional, dan religiusitas terhadap perilaku etis mahasiswa akuntansi diuji dengan menggunakan Uji t.

Berdasarkan hasil pengujian hipotesis yang pertama didapatkan nilai signifikasi sebesar 0,018 dengan nilai koefisien regresi positif sebesar $0,152 . \mathrm{H}_{0}$ ditolak dan $\mathrm{H}_{1}$ diterima. Hasil ini mempunyai arti bahwa pemahaman kode etik akuntan berpengaruh positif dan signifikan terhadap perilaku etis mahasiswa akuntansi.

Wibowo (1986) dalam penelitiannya mengenai kode etik akuntan menemukan hasil terdapat pengaruh positif dari kode etik akuntan terhadap perilaku etis dan pertimbangan etis auditor. Ernawati \& Susanti (2016) juga menemukan hal yang serupa dalam penelitian yang dilakukannya. Ernawati \& Susanti (2016) selanjutnya memaparkan pentingnya profesionalisme bagi profesi. Akuntan memiliki tugas yang berhubungan dengan laporan keuangan. Setiap perusahaan memiliki laporan keuangan terutama perusahaan yang telah go public perlu menerbitkan laporan keuangan yang telah diaudit yang kemudian digunakan oleh orang-orang yang memerlukan laporan keuangan tersebut dalam menentukan suatu keputusan. Akuntan memiliki tanggung jawab terhadap masyarakat untuk memastikan bahwa laporan yang disajikan telah sesuai dengan SAK sehingga tidak terjadi kesalahan dalam pengambilan keputusan oleh pengguna laporan keuangan.

Pengetahuan mengenai kode etik akuntan harus sudah ditanamkan sejak seseorang tersebut menempuh pendidikan untuk menjadi seorang akuntan. Oleh 
karena itu kode etik merupakan faktor penting untuk diketahui dan dimengerti oleh mahasiswa akuntansi. Enofe et al. (2014) dan Soedjatmiko, Abdullah, \& Asiah (2017) dalam penelitiannya menemukan bahwa terdapat pengaruh dari kode etik terhadap parktik kerja akuntan. Dengan hasil yang didaapatkan tersebut, maka penting adanya pemberian pengetahuan mengenai kode etik akuntan kepada mahasiswaa akuntansi karena mahasiswa akuntansi adalah calon-calon akuntan di masa yang akan datang. Dengan memberikan pengetahuan mengenai kode etik sejak masa perkuliahan, diharapkan akan meningkatkan kebiasaan mahasiswa dalam berperilaku etis dan kemudian akan terbawa ke dunia kerjanya nanti.

Berdasarkan hasil analisis pengaruh kecerdasan emosional terhadap perilaku etis mahasiswa akuntansi diperoleh nilai signifikasi sebesar 0,012 dengan nilai koefisien regresi positif sebesar 0,267. Nilai Signifikansi 0,012<0,05 mengindikasikan bahwa $\mathrm{H}_{0}$ ditolak dan $\mathrm{H}_{2}$ diterima. Hasil ini mempunyai arti bahwa kecerdasan emosional berpengaruh positif dan signifikan terhadap perilaku etis mahasiswa akuntansi. Pemimpin dalam organisasi merupakan role model bagi anggotanya. Ketika pemimpin dapat memberikan contoh perilaku yang baik maka anggota tim cenderung akan memiliki perilaku yang baik juga. Begitu juga dengan kepatuhan pemimpin terhadap kode etik dari profesi yang dijalaninya. Dengan memiliki pemimpin atau individu yang patuh terhadap kode etik profesi yang berlaku maka individu tersebut dapat dikatakan sukses karena berperilaku etis dalam pekerjaan merupakan faktor penting dalam mencapai kesuksesan dalam karir seseoraang (Morgan, 1993). Menurut Larkin (2000) memiliki pengetahuan untuk dapat melihat perilaku yang dikategorikan etis dan yang tidak dikategorikan 
etis sangat berguna baagi semua profesi begitu juga profesi akuntan.

Simanjorang \& Sipayung (2012) dalam penelitiannya menemukan kecerdasan emosional memiliki pengaruh yang positif pada perilaku etis mahasiswa. Lucyanda (2013) juga menemukan hasil yang sama dalam penelitiannya. Lucyanda (2013) selanjutnya mengemukakan bahwa kecerdasan emosional memiliki pengaruh yang cenderung dominan jika dibandingkan dengan kecerdasan lain yang menjadi variabel dalam penelitiannya. Alasan dari temuan tersebut adalah dengan berkembangnya kecerdasan emosional seseorang akan diikuti dengan perkembangan kecerdasan lainnya. Said \& Rahmawati (2019), Handayani (2010) dalam penelitiannya menemukan bahwa kecerdasan emosional berpengaruh terhadap sikap etis dari mahasiswa akuntansi.

Berdasarkan hasil analisis pengaruh religiusitas terhadap perilaku etis mahasiswa akuntansi diperoleh nilai signifikasi sebesar 0,013 dengan nilai koefisien regresi positif sebesar 0,293. Nilai Signifikansi $0,013<0,05$ mengindikasikan bahwa $\mathrm{H}_{0}$ ditolak dan $\mathrm{H}_{3}$ diterima. Hasil ini mempunyai arti bahwa religiusitas berpengaruh positif dan signifikan terhadap perilaku etis mahasiswa akuntansi.

Handayani (2010) dengan judul penelitian "Faktor - Faktor yang Mempengaruhi Perilaku Etis Mahasiswa Akuntansi Universitas Islam Lamongan” mendapatkan hasil semakin baiknya tingkat kecerdasan spiritual mahasiswa akan berdampak terdahap baiknya perilaaku etis mahasiswa tersebut. Riasning et al., (2017) memberikan penjelasan mengenai bagaimana seseorang dengan tingkat kecerdasan spiritual tinggi cenderung memilih untuk mengembangkan dirinya 
pada aktivitas yang positif. Lucyanda (2013) dan Husein, (2008) mengungkapkan mahasiswa dengan kecerdasan spiritual yang tinggi cenderung mempertimbangkan perilakunya dan selalu berpikir untuk berperilaku yang tidak menyimpang.

\section{SIMPULAN}

Pemahaman kode etik akuntan berpengaruh positif signifikan terhadap perilaku etis mahasiswa akuntansi. Pengetahuan mengenai kode etik akuntan harus sudah ditanamkan sejak seseorang tersebut menempuh pendidikan untuk menjadi seorang akuntan. Oleh karena itu kode etik merupakan faktor penting untuk diketahui dan dimengerti oleh mahasiswa akuntansi.

Kecerdasan emosional berpengaruh positif signifikan terhadap perilaku etis mahasiswa akuntansi. berkembangnya kecerdasan emosional seseorang akan diikuti dengan perkembangan kecerdasan lainnya

Religiusitas berpengaruh positif signifikan terhadap perilaku etis mahasiswa akuntansi. seseorang dengan tingkat kecerdasan spiritual tinggi cenderung memilih untuk mengembangkan dirinya pada aktivitas yang positif. Mahasiswa dengan kecerdasan spiritual yang tinggi cenderung mempertimbangkan perilakunya dan selalu berpikir untuk berperilaku yang tidak menyimpang.

\section{REFERENSI}

Bertens, K. (2000). Penerbit Kanisius. Yogyakarta: Pengantar Etika Bisnis. 
Catarina. (2010). Pengaruh Kepemimpinan Transformasional Dan Kecerdasan Emosional Terhadap Kinerja Karyawan. Jakarta: Pt. Gramedia Pustaka Utama.

Chan, S. (2006). "The Effects Of Acounting Students" Ethical Reasoning And Personal Factors On Their Ethical Sensitivity". Managerial Auditing Journal, $21(4), 436-457$.

Davis, J. R., \& Welton, R. E. (1991). Professional Ethics: Business Students' Perceptions. Journal Of Business Ethics, 10(6), 451-463. Https://Doi.Org/10.1007/Bf00382829

Enofe, A. O., Nakpodia, J. O., \& Moruku, J. A. (2014). Ethics And Role Of Accountants. European Journal Of Business And Managementonline), 6(27), $2222-2839$.

Ernawati, N., \& Susanti, D. A. (2016). Pengaruh Pemahaman Kode Etik Profesi Akuntan Terhadap Perilaku Etis Mahasiswa Akuntansi Universitas Muria Kudus. Jurnal Ekonomi, 4(2), 101-208.

Gberegbe, F. B., \& Gabriel, A. (2016). Does Professional Code Of Ethics Influence Professional Accounting Practice In Rivers State, Nigeria? Lilian Okorite Nkanbia-Davies, 4(1), 14-21.

Goleman, D. (2002). Working With Emotional Intelligence. Jakarta: Pt. Gramedia Pustaka Utama.

Green, L. W., \& Kreuter, M. . (2000). Health Promotion Planning An Educational And Environmental Approach (2nd Ed.). Mayfield Publishing Company.

Handayani, S. (2010). Faktor Faktor Yang Mempengaruhi Perilaku. Pengantar Psikologi Dalam Keperawatan, 33.

Higgs, M. (2014). Do Leaders Need Emotional Intelligence? A Study Of The Relationship Between Emotional Intelligence And Leadership Change Do Leaders Need Emotional Intelligence?: A Study Of The Relationship Between Emotional Intelligence And, (January 2002).

Husein, M. F. (2008). Fakhri 2008 Komitmen Org, Ethics Behaviour Terhadap Job Satisfaction (Indo), (1), 31-55.

Larkin, J. M. (2000). The Ability Of Internal Auditors To Identity Ethical Dilemmas. Journal Of Business Ethics, 23, 401-409.

Lucyanda, J. (2013). Faktor-Faktor Yang Mempengaruhi Perilaku Etis Mahasiswa Akuntansi Universitas Bakrie. Jurnal Ekonomi Dan Ilmu Sosial, 2(2), 1-34. 
Mcdaniel, S.W ., \& Burnett, J.J. (1990). Consumer Religiosity And Retail Store Evaluative Criteria. Journal Of The Academy Of Marketing Science, 18(2), 101-112.

Melandy, R., \& Nurma, A. (2006). Pengaruh Kecerdasan Emosional Terhadap Tingkat Pemahamanakuntansi, Kepercayaan Diri Sebagai Variabel Pemoderasi. Simposium Nasional Akuntansi.

Morgan, R. B. (1993). Self And Co-Worker Perceptions Of Ethics And Their Relationships To Leadership And Salary. Academy Of Management Journal, 36.

Mulyadi. (2002). Auditing (Pengauditan), Buku I (6th Ed.). Pt. Salemba Empat.

Ramly, Z. (2008). Religiosity As A Predictor Of Consumer Ethical Behaviour: Some Evidence From Young Consumers From Malaysia, 3(4), 43-56.

Reiss, M. C., \& Mitra, K. (1998). The Effects Of Individual Difference Factors On The Acceptability Of Ethical And Unethical Workplace Behaviors, 1581-1582.

Revita Mardawati. (2016). Pengaruh Orientasi Etis, Gender, Dan Pengetahuan On The Perception Of Accounting Students On Accountant ' S, 1-15. Retrieved

Fromhttp://Journal.Student.Uny.Ac.Id/Ojs/Index.Php/Profita/Article/Downlo $\mathrm{ad} / 5889 / 5628$

Riasning, N., Datrini, L., \& Putra, I. (2017). Pengaruh Kecerdasan Intelektual, Kecerdasan Emosional Dan Kecerdasan Spiritual Terhadap Sikap Etis Mahasiswa Akuntansi Di Kota Denpasar. Jurnal Krisna: Kumpulan Riset Akuntansi, 9(1).

Said, A. N., \& Rahmawati, D. (2019). Pengaruh Kecerdasan Intelektual, Kecerdasan Emosional Dan Kecerdasan Spiritual Terhadap Sikap Etis Mahasiswa Akuntansi (Studi Empiris Pada Mahasiswa Prodi Akuntansi Universitas Negeri Yogyakarta). Nominal, Barometer Riset Akuntansi Dan Manajemen, 7(1). Https://Doi.Org/10.21831/Nominal.V7i1.19357

Setyawan, D. (2004). Analisis Pengaruh Kepemimpinan (Iq, Eq, Sq) Terhadap Komitmen Organisasional Karyawan (Unpublishe). Semarang: Universitas Katolik Soegijapranata.

Simanjorang, D., \& Sipayung, F. (2012). Pengaruh Kecerdasan Intelektual, Kecerdasan Emosional Dan Kecerdasan Spiritual Terhadap Sikap Etis 
Mahasiswa Manajemen Fakultas Ekonomi Universitas Sumatera Utara. Jurnal Ekonom, 15(2), 5-6.

Soedjatmiko, Abdullah, H., \& Asiah, N. (2017). Pengaruh Pemahaman Kode Etik Profesi Akuntan Terhadap Perilaku Etis Pada Mahasiswa Stie Nasional Banjarmasin. Dinamika Ekonomi. Jurnal Ekonomi Dan Bisnis, 10(2), 18-35.

Svyantek, D. . (2003). Emotional Intelligence And Organizational Behavior. The International Journal Of Organizational Analysis, (11), 167-169.

Tikollah, R., Triyuwono, I., \& Ludigdo, U. (2006). Pengaruh Kecerdasan Intelektual, Kecerdasan Emosional Dan Kecerdasan Spiritual Terhadap Sikap Etis Mahasiswa Akuntansi. Simposium Nasional Akuntansi (Sna) Ix Padang, $23-28$.

Wibowo, A. (1986). Pengaruh Kode Etik Akuntan , Personal Ethical Philosophy, Corporate Ethical Value Terhadap Persepsi Etis Dan Pertimbangan Etis Auditor ( Studi Empiris Pada Kantor Akuntan Publik Di Jakarta ). Serat Acitya Jurnal Ilmiah, No Volume.

Wiyono, M. W. (2012). Sarcoid Of Boeck. Journal Of The Royal Society Of Medicine, 27(10), 1364-1365. Https://Doi.Org/10.1177/003591573402701034

Yanti, I. (2012). Pengaruh Kecerdasan Spiritual Terhadap Kinerja Auditor Pada Kantor Akuntan Publik (Studi Empiris Pada Provinsi Riau Dan Sumatra Barat). Pekanbaru: Universitas Riau.

Zohar, D., \& Marshall, I. (2007). Sq: Kecerdasan Spiritual. (Rahmani Astusti, Ahmad Nadjib Burhani, Ahmad Baiquini. Terjemahan). Bandung: Pt Mizan Pustaka. 